\title{
Financial Performance Competency Analysis of Sharia Micro Financial Institution and Its Relationship with Small and Medium Enterprise Development in Sumenep Madura
}

\author{
Mohamad Heykal \\ Accounting Department, Faculty of \\ Economic and Communication \\ Bina Nusantara Unversity \\ Jakarta, Indonesia \\ mheykal@binus.edu
}

\author{
Astri Furqani \\ Accounting Department \\ Wiraraja University \\ Madura, Indonesia
}

Lidiawati

Accounting Department, Faculty of

Economic and Communication

Bina Nusantara Unversity

Jakarta, Indonesia

\author{
Banon Amelda \\ Accounting Department, Faculty of \\ Economic and Communication \\ Bina Nusantara Unversity \\ Jakarta, Indonesia
}

\begin{abstract}
The aim of this study is to see the impact of the performance competence of Islamic microfinance institutions as well as the development of micro and medium small enterprises in Sumenep, Madura region. This research used nonexperimental method with survey technique with Guttman scale to LKMS and UMKM in Sumenep regency. While the sampling technique was by purposive sampling to the population and obtaining 46 samples. Based on the results of the validity and reliability test, it is known that the test equipment used is quite valid and reliable, so it can be used in this study. Data analysis used descriptive analysis and correlation analysis to see the relationship between variables with each other. The results of the data obtained for the competence of achievement of capital management indicators is the management of the most important and prominent indicators with an average value of $82.07 \%$, while the most prominent indicator relationship counseling competence is general management with an average value of $85.15 \%$. While in terms of correlation, MSME development in Sumenep Regency is very influenced by competence of achievement of result of capital management indicator, with correlation value with significance 0.04 and competence of relationship building from effectiveness of service to society.
\end{abstract}

Keywords: Financial Performance Competency Analysis, Sharia Micro Financial Institution, Small and Medium Enterprise Development

\section{INTRODUCTION}

Islamic financial institutions are part of the implementation of Islamic economic system which runs business and business activities based on Islamic principles consisting of banks and non-banks. In this case a financial institution and also a microfinance institution Sharia, one of them is the BMT. BMT will be very beneficial for the community because the agency does not use a system that can incriminate banks such as conventional banks. However, the competitive conditions of BMTs with conventional banks or with BPRs discussing them to find appropriate strategies in developing BMTs with roads and the environment of each BMT. On the other hand also BMT has a number in the market. The market share of BMT as well as other Islamic microfinance institutions is just around the district alone. Nisbah or profit and loss sharing of BMT is smaller with other sharia financial institutions On this basis, from those BMT is very beneficial for middle-low society.

However, the main factors that determine the formation of Islamic micro finance institution, especially in Indonesia have not been extensively studied. Known as sharia financial institutions that follow the values contained in the Islamic Shari'a. BMT does not contain usury in the financing to the public.

Similar to financial institutions, BMT has a function as a bridging intermediary between depositor and investors. In addition, the relationship between BMT and customers is a partner of the lender or borrower, so that these Islamic financial institutions can act as sellers, buyers and leasing parties. The products offered by BMT vary widely with mutually beneficial principles and uphold the principles of justice. Therefore, BMT is not solely to seek profit and stacking of capital earnings in a group of rich people, but rather orientate to equitable and fair profit distribution in accordance with Islamic economic principles. Because it is interesting to examine and also see the development of BMT in a district district in Indonesia, in this case is Sumenep district.

Sumenep is regencies in East Java Province, located on the eastern tip of Madura Island have potential development potential of small micro and medium enterprises big enough. As in Sampang, for example, based on data obtained from the Office of Cooperatives and Small Medium Enterprises local is known there are about 27,155 SMEs. While in Sumenep, the data received reached 22,156. This amount is certainly a potential that should be developed by microfinance institutions, including in this case the Islamic microfinance institutions in the region. In this case the roles of BMT and sharia micro finance institutions become very important.

\section{LITERATURE REVIEW}

According to Effendi (2010) states that Islamic microfinance institutions are part of the concept of Islam 
which is implemented that the state basically has a clear goal where will the establishment of a prosperous and safe Islamic society. In Islamic micro finance concept there are BMT, sharia cooperative and also BPRS. In addition, according to Rahman (2007) that Islamic microfinance institutions is one thing that should not be ignored in the development of Islamic financial institutions because it proved successful in alleviating poverty. Indonesia is one of four countries categorized as a leader in the development of microfinance, including microfinance of sharia.

BMT is basically the abbreviation of Baitul Mal wa Tamwil In the concept of baitul maal that means home fund while the concept of baitul tamwil means home business. Baitul Maal is usually developed based on the history of its development, ie from the time of prophet to medieval development of Islam. Where baitul maal serves to collect as well as to distribute various social funds, but baitul tamwil is a business institution with profit motive. On that basis, the BMT is a combination of these two types of activities. Baitul Maal wat tamwil is also an integrated self- supporting entity whose activities are a combination of baitul maal and baitut tamwil. The objective of the establishment of BMT is to develop various productive activities as well as investments in order to improve economic activities of small, medium and low entrepreneurs by encouraging the development activities and raising of third party funds as well as supporting the financing of economic activities.

Table 1. Development of MSMEs in Sumenep -East Java, 2011-2015

\begin{tabular}{|c|c|c|c|c|c|c|}
\hline No & $\begin{array}{l}\text { Type of } \\
\text { business } \\
\text { activities }\end{array}$ & 2011 & 2012 & 2013 & 2014 & 2015 \\
\hline 1 & $\begin{array}{l}\text { Active } \\
\text { cooperatives }\end{array}$ & 760 & 814 & 1.278 & 859 & 768 \\
\hline 2 & $\begin{array}{l}\text { SME's: Non- } \\
\text { Rural } \\
\text { Banks/Micro } \\
\text { Finance } \\
\text { Institutions }\end{array}$ & 1.324 & 1.589 & 1.780 & 1.140 & 2.173 \\
\hline 3 & $\begin{array}{l}\text { Rural } \\
\text { Banks/Micro } \\
\text { Finance } \\
\text { Institutions }\end{array}$ & 753 & 556 & 5565 & 556 & 815 \\
\hline 4 & $\begin{array}{l}\text { Micro Small } \\
\text { Enterprises } \\
\text { (MSE) }\end{array}$ & 21.686 & 22.125 & 23.120 & 23.400 & 23.140 \\
\hline
\end{tabular}

Source: Local Government of East Java (2016)

Given the limited access and capital, it is expected that the development of this small and medium enterprise sector will be able to encourage the availability of employment that will impact on the decrease of unemployment. In addition, small and medium enterprises can also be a new growth engine, with high growth rates although productivity per worker is low. Group of small, medium and cooperative business is a form of economic life of most people of Indonesia. The existence of this group cannot be separated from the national economic growth. Groups of small, medium and cooperative enterprises are able to absorb more than 64 million workers and contribute approximately $58.2 \%$ in the formation of Equity Products in the distribution of development.

Competence is defined as Skills or knowledge, abilities, as well as behavior of the workers in an organization that will usually greatly affect the success of an institution. Zwell in Rafidah (2014) divides the competency category into 5 (five), from five categories are subdivided into types of competence, namely: a. Achievement Competence Results; b. Relationship Coaching Competencies c. Personality Attribute Competence; d. Managerial Competence; e. Leadership Competencies

According Rafidah (2014), improvement of competence here is the improvement of team-based skills with the aim of empowerment and talent development. Human resources are a unique capital because in addition to difficult to imitate this capital is also difficult to replace. Marsdan (1998) introduces a competency approach in achieving competitive advantage and is called competence based Approach. Wirawan (2009:5) defines performance as the output generated by indicators of a job within a certain time. Meanwhile Sucipto (2003) in Pramono (2015) defines financial performance is the determination of certain measures that can measure the success of an organization or company in generating profit. Meanwhile, according to IAI (2007:18) Financial Performance is the company's ability to manage and control its resources. From the above understanding can be concluded that the financial performance is the ability of companies or organizations in managing the resources measured in a certain period to generate profits.

\section{Materials AND Methodology}

Data collection method used non-experimental method with survey techniques, those is collecting data as much as possible with questionnaires to get information data about competence of financial performance of Sharia Micro Financing Institution and development of UMKM in Sumenep Regency East Java Province. Populations in this research are all Micro Finance Institution (LKM) and UMKM that exist in Sumenep Regency of East Java Province which amount 115 LKMS. The sampling technique in this research is done by purposive sampling with the following criteria: (1). Micro Finance Institution (LKM) in Sumenep Regency of East Java Province; (2). MFI's which have a business unit of savings and loans; (3). Saving and loan in accordance with Sharia principles, and; (4). Still be active until 2016. Based on the above criteria obtained 46 LKMS to be used as a sample. Independent variables include: Competence Achievement of results and competence Guiding Relationship with dependent variable Development of MSMEs.

The authors tested the validity and reliability of the test equipment to be used in this study. In a study to test the validity of the author using Skalo software Scale Analysis program version 2.0 of Wahyu Whidiarso. While for the reliability test using the formula of Kuder Richardson 20 or commonly abbreviated as KR 20 . The result of validity test by using Reproducibility coefficient and Scalability coefficients shows that of total 39 items of questions included in the instrument or questionnaire, one question for item no. 1 of the capital management variables are eliminated because it has a high error rate. So the total of question items becomes 38 items and the instruments consisting of 6 independent variables and 1 dependent variable are valid as shown in table 2 below. 
Table 2. Guttman Scale Validity Test Results

\section{RESULTS AND DISCUSSION}

\begin{tabular}{|c|c|c|c|c|c|}
\hline $\begin{array}{l}\text { Variable } \\
\text { type }\end{array}$ & Variable & Indicator & $\begin{array}{l}\mathrm{CR}> \\
0.90\end{array}$ & $\begin{array}{l}\mathrm{CS}> \\
0.60\end{array}$ & Information \\
\hline \multirow[t]{6}{*}{ Independet } & $\begin{array}{l}\text { Compete } \\
\text { nce } \\
\text { Achieve } \\
\text { ment of } \\
\text { results } \\
\text { (X1) }\end{array}$ & $\begin{array}{l}\text { Effective } \\
\text { ness of } \\
\text { Financial } \\
\text { Statemen } \\
\text { ts }\end{array}$ & 0.94 & 0.88 & valid \\
\hline & & $\begin{array}{l}\text { Capital } \\
\text { Manage } \\
\text { ment }\end{array}$ & 0.96 & 0.91 & $\begin{array}{l}\text { Valid, no. } 1 \\
\text { elimination }\end{array}$ \\
\hline & & $\begin{array}{l}\text { Assets } \\
\text { Manage } \\
\text { ment }\end{array}$ & 0.91 & 0.81 & valid \\
\hline & $\begin{array}{l}\text { Compete } \\
\text { nce of } \\
\text { relationsh } \\
\text { ip } \\
\text { building } \\
(\mathrm{X} 2)\end{array}$ & $\begin{array}{l}\text { Effective } \\
\text { ness of } \\
\text { services } \\
\text { to the } \\
\text { communi } \\
\text { ty } \\
\text { (MSMEs } \\
\text { ) }\end{array}$ & 0.85 & 0.69 & Quite valid \\
\hline & & $\begin{array}{l}\text { General } \\
\text { Manage } \\
\text { ment }\end{array}$ & 0.90 & 0.80 & valid \\
\hline & & $\begin{array}{l}\text { Institutio } \\
\text { nal } \\
\text { Manage } \\
\text { ment }\end{array}$ & 0.82 & 0.63 & Quite valid \\
\hline Dependent & $\begin{array}{l}\text { Develop } \\
\text { ment of } \\
\text { MSMEs }\end{array}$ & $\begin{array}{l}\text { Effective } \\
\text { ness of } \\
\text { Existence } \\
\text { of } \\
\text { Islamic } \\
\text { Microfin } \\
\text { ance }\end{array}$ & 0.97 & 0.94 & valid \\
\hline
\end{tabular}

Source: Primary data.

Meanwhile, from the calculation results with the formula KR-20 obtained reliability test results for each variable compared with the category reliability coefficient according to (Guiford, 1965: 145) as listed in table 3 note that the instrument is reliable and can be used for research.

Table 3. Guttman Scale Reliability Test Results

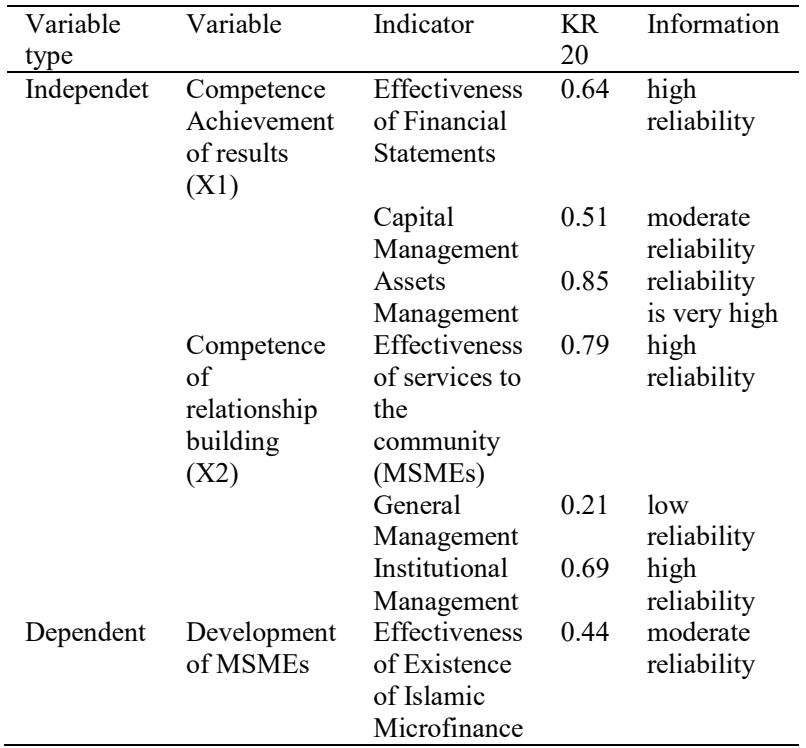

Source: Primary data.

\section{A. Descriptive analysis}

The results achievement competence (X1) in this research includes three indicators of assessment, namely, effectiveness of financial statements, capital management and asset management. Of the 3 indicators, capital management is an important indicator of Achievement Achievements competitiveness with an average of $82.07 \%$, while asset management occupies the lowest rank of $34.06 \%$. Based on the results of frequency distribution and respondent interpretation for capital management, average $82.07 \%$ respondents (38 Islamic microfinances) in Sumenep District East Java Province assessed capital management indicators is the most important indicator to assess the financial performance competence of LKMS. As an institution engaged in the field of saving and loan business of good capital of course become the main basis in developing its business. Almost all Islamic microfinances in Sumenep District have conducted evaluation in their capital management. However, the number of Islamic microfinances that has been well managed is only $60.87 \%$ (28 Islamic microfinances), where the Islamic microfinances have made a commitment on capital adequacy, risk assessment and taking precautionary measures to deal with risk. Meanwhile, several other Islamic microfinances in capital management only take risk precautions without conducting risk assessments first. It can be concluded that Islamic microfinances in Sumenep Regency in managing capital more prioritize evaluation of capital management from risk side and prevention. Though as one of the institutions engaged in the business of financing the assessment of capital adequacy is important, although the risk is also important.

Almost all Islamic microfinances in Sumenep or $97.83 \%$ of respondent rate, the increasing competence of achievement result caused by the effectiveness in preparing financial statements that meet accounting standards generally accepted, systematic, timely and delivered in a transparent and accountable. While Islamic microfinances assess the audit process in the financial statements of Islamic microfinances considered less important. Because only 39.13\% (18 Islamic microfinances) alone who perform the audit process to the financial statements he prepared. This is certainly contrary to previous respondents' answers that the financial statements Islamic microfinances effective one of them is the financial statements are transparent and accountable. This means that from 45 Islamic microfinances in Sumenep District only about one third or only $30 \%$ of Islamic microfinances financial statements that really can be accounted for its report or accountable, while the remaining $70 \%$ doubt.

In addition, Islamic microfinances in Sumenep Regency rarely evaluates its financial statements in terms of profit or profit, liquidity or debt. Only about 26 Islamic microfinances are evaluating or valuing profit, liquidity or debt. In fact, the assessment of these three ratios is very important for an Islamic microfinance that has a major business to measure the success of sharia micro finance in financial performance. Of course, this needs special attention to local government and Islamic microfinances in improving financial performance.

In terms of asset management, on average only $34.06 \%$ (16 Islamic microfinances) perform asset management. Of the 46 existing Islamic microfinances, only $28.26 \%$ (13 Islamic 
microfinances) with fixed asset value (> 50\%) and 41.30\% (19 Islamic microfinances) return on capital from the results can be realized quickly (less than one year). This means that the receivable turnover of Islamic microfinances in Sumenep Regency almost as big slow or more than one year, this could be due to inefficient financial performance of Islamic microfinances so far that the turnover of capital becomes so slow.

The Relationship Competence (X2) includes 3 (three) indicators of assessment, namely: general management, institutional management and Effectiveness of services to the community (MSMEs). Based on the survey results, the 3 indicators of competence in the development of general management relationships are the most important indicators and the most prominent in the relationship coaching competence with an average score of $85.15 \%$ or 40 Islamic microfinances.

Islamic microfinances as institutions engaged in saving and loan business activities by implementing Sharia principles. Almost all or 43 Islamic microfinances in Sumenep regency know and are very obedient to the policies and rules related to the business management of Islamic microfinances. However, out of 43 Islamic microfinances that understand and adhere to government or BI regulations and policies, most or 30 Islamic microfinances experience difficulties or difficulties in complying with the rules or policies. Of course, this is the task of the government, BI, OJK and the policy holder to be able to transmit information related to financial rules and regulations for Islamic microfinances continuously and clearly so that easily translated by policy users as Islamic microfinances.

The average of $55.43 \% \%$ or 26 Islamic microfinances assess good institutional management can improve the relationship or good cooperation between Islamic microfinances with its customers or other external parties. Islamic microfinances in Sumenep Regency of Java Province that has fulfilled good corporate governance has only reached 27 Islamic microfinances. Most Islamic microfinances have self-governance. In running the company some Islamic microfinances still face obstacles in its management. Meanwhile, the effectiveness of the service to the community has not been maximized; only 30 Islamic microfinances stated that the Islamic microfinances service to the community has been effective. Of all the existing Islamic microfinances, only 13 provide services to the public without any effort. Financing to finance new business is only provided by 12 . Meanwhile, the other 34 Islamic microfinances only provide financing for existing businesses.

In managing the capital of its business, Islamic microfinances in the District is quite selective in providing financing to the community, there are about 29 Islamic microfinances which stipulates the requirement in giving financing to MSMEs requests record of financial report from MSME who apply for financing and existence of guarantee from MSMEs to borrow capital. From the total number of Islamic microfinances in Sumenep there are 21 that have refused to give financing to MSMEs. Rejection of such financing may be due to the non-fulfillment of the requirements submitted by the Islamic microfinances to MSMEs so that it refused to provide financing.
Based on survey results revealed that the development of SMEs in Sumenep Regency of East Java Province is the impact of the effectiveness of Islamic microfinances presence in the region, which the effectiveness of Islamic microfinances presence to SMEs of $55.43 \%$. Respondents assess the effectiveness of the existence of Islamic microfinances to MSMEs can be seen from the increase of membership of SMEs every year at 43 Islamic microfinances, the support of resources that understand finance and the existence of branch offices provide facilities for the community or SMEs to be able to take advantage of the Islamic microfinances. However, there are still few branch offices of Islamic microfinances, with only 3 Islamic microfinances having branch offices causing MSME development in Sumenep Regency to fluctuate, although in 2015 MSMEs increased 4\% from the previous year, but the increase is still low. It needs hard effort from local government to be able to increase Islamic microfinances empowerment to finance MSMEs, so that the development can continue to increase and open job opportunity for local community besides increasing income for regional income.

\section{B. Correlation analysis}

Correlation between variables Competence Achievement Results Financial Statement Effectiveness (X11) and Development of MSME (Y) amounted to - 0.064, showing a very weak relationship and not unidirectional. This means that the increased effectiveness of Islamic microfinances' financial statements as the competence of Achievement of Results will not affect the development of MSMEs in the region Sumenep East Java, because the correlation is very weak. Signification shows 0.672> 0.05. This means that the indicator effectiveness of financial statements in the competency of achievement of the results is not significant.

Correlation value between competence variable of Capital Management Performance Result (X12) and Development of MSMEs (Y) equal to 0,420 , showing strong relation and direction. This means that the adanyanya capital management as an indicator in Achievement Competence Results strong enough to affect the increasing development of MSMEs in the region Sumenep Madura and significant, with a significance value of $0.004<0.01$, therefore needs to be controlled and managed properly.

The correlation values between competence Achievement Results Asset Management (X13) and Development of MSME (Y) of 0.071, indicating a very weak relationship and direction. This means that the existence of asset management as an indicator in Achievement Competence Results quite significantly influence with the significance value $0.004<0.01$ to increase the development of SMEs in the region Sumenep Madura. So the management of fixed assets needs to be considered and well managed as an indicator in the competence of achievement of results.

A perfect correlation value can be found between the variables of Relationship Development: Effectiveness of Services to the Community (UMKM) (X21) with MSME Developments (Y) of 1,000. This means that the development of SMEs in the region of East Sumenep Regency is greatly influenced by the increase in the Competence of Relationship Development, especially from the effectiveness of services to the community (MSMEs), this is indicated by the perfect correlation of both variables. Therefore, the improvement on 
the financial performance of Islamic microfinances especially the service to the community will greatly affect the mining of MSMEs in the region of East Sumenep Regency significantly, where the significance shows lower than 0.01 .

Correlations between Competence Leading of Management General Relationship (X22) and MSME (Y) growth of $-0,080$. This means that both variables have a very weak relationship and not unidirectional. It is not in the same direction those the existences of good general management in this case is the compliance in legal and regulations related to the financial field as an indicator in the Competence Development Relationship does not give a strong influence on the development of SMEs in the region Sumenep Madura. Because of the weakness' and no significant correlations among two variables, those is indicated by the significance of the correlation between the two variables higher than 0.05 .

Correlation between competence leading relationship of institutional management (X23) and development of MSME (Y) growth of $-0,047$. This means that both variables have a very weak relationship and not unidirectional. It is not the same direction as the management of good institutional management in this case is the existence of good governance of LKMS as an indicator in the Competence Development Relationship does not give a strong effect it shows very weak and insignificant correlation to the development of SMEs in the region Sumenep Madura regency. This is indicated by the significance of the correlation between the two variables 0.757 higher than 0.05 .

\section{CONCLUSION}

Based on the results obtained by the researchers above, it can be concluded as follows. The capital management indicator is the most important indicator to assess the financial performance of LKMS from the achievement of the result with the mean of $82,07 \%$. Because capital is a major factor for a financial institution, in this case LKMS. As an institution engaged in the field of saving and loan business of good capital of course become the main base in developing its business. In the assessment of competency guidance the most prominent indicator relationship is general management with a mean of $85.15 \%$. Where as an institution engaged in lending activities by running the principles of Sharia, almost all or 43 Islamic microfinances in Sumenep regency knows and is very obedient to the policies and rules related to the business management of Islamic microfinances.

Based on survey results conducted by the research team it is known that the development of MSMEs in Sumenep Regency East Java Province is the impact of effectiveness of Islamic microfinances presence in the region, which the effectiveness of existence of Islamic microfinances to MSME is $55,43 \%$. Respondents assessed the effectiveness of the existence of Islamic microfinances to MSMEs that can be seen from the increase of membership of SMEs every year at 43 Islamic microfinances, the support of resources that understand finance and the existence of branch offices provide facilities for the community or SMEs to be able to take advantage of the Islamic microfinances. Increasing the financial performance of Islamic microfinances especially services to the community will greatly affect the development of MSMEs in the region of East Sumenep Regency significantly, where the significance shows lower than 0.01 .

\section{REFERENCES}

[1] Ashari .(2006). Potential of Micro Finance Institution (MFI) in Rural Economic Development and Development Policy. Indonesian Center for Agriculture Socio Economic and Policy Studies. Bogor.

[2] Amalia, Euis. (2008)." Distributive Justice in Islamic Economics", Dissertation. Page. 65.

[3] Guilford, J.P. (1956). Fundamental Statistic in Psychology and Education. 3rd Ed. New York: McGraw-Hill Book Company, Inc.

[4] Hernawa, Rachmanto .(2006). Analysis of Sharia Bank Health Level Using Camel Method, Islamic University of Indonesia, Yogyakarta.

[5] Hero. (2009). Human Resources Performance Evaluation. Jakarta: Salemba Four.

[6] Indonesian Institute of Accountants. (2007). Financial Accounting Standards as of September 1, 2007. Salemba Four. Jakarta

[7] Madison, Journal of the People's Economy. www.ekonomirakyat.org

[8] Pramono, Deny and Budiyanto (2015). Financial Ratio Analysis to Assess The Financial Performance of Mining And Mineral Mining Companies. Journal of Management Science and Research, 4(.9),116.

[9] OJK, General information of microfinance institutions. http://www.ojk.go.id/id/kanal/iknb/Pages/Lembaga-KeuanganMicro.aspx

[10] Rafidah (2014). Competency Analysis on Financial Performance at Shariah Micro Financial Institution of Jambi City. Reason of Fiqh, 9(1), 1-25

[11] Republic of Indonesia, Law No.1 Year 2013 on Micro Finance Institutions, Chapter 1, Article 1

[12] Munggaran, D.R.(2012). Utilization of Open Source Software Education by Students in the Framework of Implementation of Law No.19 of 2002 on Intellectual Property Rights.Essay.Bandung. Indonesia University of Education.

[13] Subramanyam K.R, Wild Jhon J.(2014). Financial Statement Analysis. Edition 10. Salemba Four. Jakarta.

[14] Whidiarso, Wahyu. (2011). Skalo Guttman Scale Analysis Program. http://widhiarso.staff.ugm.ac.id/wp/skalo-program-analisis-skalaguttman/2017.12.13

[15] Yulian, Findawati, Astutik Ika Ratna Indra.(2016), Web Application of Performance Measurement of Micro Finance Institution Using Fuzzy-AHP Method, WPM And Balanced Scorecard. Journal of Information Systms University of Indonesia, 12(1), 30-40. 